\title{
SUBSTANTIATION OF THE CONCEPT OF FORMATION OF PROJECT COMPETENCE OF FUTURE BACHELORS OF SOCIAL WORK
}

Обгрунтування концепції формування проєктної компетентності майбутніх бакалаврів соціальної роботи здійснюється на основі стратегії змішування методів, в інтеграції різних методологічних підходів. У статті концепція фрормулюється в частинах щодо структури педагогічної системи, ї цілей і змісту, а також обгрунтування інструментарію. Обгрунтування концепціі в частині структури педагогічної системи реалізовано шляхом інтеграції висновків системного та синергетичного підходів. Обгрунтування концепції в частині цілей змісту педагогічної системи здійснюється 3 використанням стратегії «перехрещення» історичного, тезаурусного й особистісно орієнтованого підходів. В обірунтуванні концепиії в частині інструментарію педагогічної системи застосовується стратегія «послідовних внесків» на основі діяльнісного, андрагогічного, комунікативного, культурологічного та праксеологічного підходів. Як результат отримано інтегральне фрормулювання концепції, що включає таке. Цілі та зміст педагогічної системи фрормування проєктної компетентності майбутніх бакалаврів соціальної роботи беруть початок від селфрпроєктної діяльності студентів, надаючи їм змогу вибирати профессійну спрямованість. Проєктна компетентність передбачає здатність майбутнього сочіального працівника на підставі власного досвіду самопроєктування виконувати фоункції співавторства у селфпроєктній діяльності клієнта, а також фуункиії соціально-педагогічної проєктної діяльності відповідно до потреб конкретних чільових груп у тезаурусі та стандартах соціальної роботи, соціально-педагогічної проєктної діяльності інноваційного характеру в умовах невизначеності. При цьому в студентів має бути сорормоване розуміння проєктної діяльності срахівця як вбудованих у ширші процеси реформування системи надання сочіальних послуг. У відповідь на складність сучасних соціальних систем педагогічна система забезпечує зростання складності проєктної компетентності студентів, збільшення кількості компонентів, які вони здатні усвідомити як елементарні та включити в поле власної профресійної активності. Комунікація в педагогічній системі формування проєктної компетентності майбутніх бакалаврів соціальної роботи реалізується як комунікаційна ситуація «спільності кількох». Підсилюється потужність педагогічної системи як синергетичної через співпрацю та взаємну допомогу студентів у реалізації проєктів, через розвиток згуртованості та самоврядування майбутніх бакалаврів, а також через чілеспрямоване включення в педагогічну систему роботодавців-наставників.

Ключові слова: проєктна компетентність, майбутні бакалаври соціальної роботи, системний підхід, синергетичний підхід, історичний підхід, тезаурусний підхід, особистісно орієнтований підхід, діяльнісний підхід, андрагогічний підхід, комунікативний підхід, культурологічний підхід, праксеологічний підхід, концепція, педагогічна система.

Substantiation of the concept of formation of project competence of future bachelors of social work is carried out on the basis of strategy of mixed methods research with integration of various methodological approaches. In the article, the concept is formulated in parts of the structure of the pedagogical system, its goals and content, as well as the justification of the toolkit. Substantiation of the concept in terms of the structure of the pedagogical system is realized by integrating the conclusions of systemic and synergetic approaches. Substantiation of the concept in terms of goals and content of the pedagogical system is carried out using the strategy of convergent of historical, thesaurus and personality-oriented approaches. In the substantiation of the concept in the part of the tools of the pedagogical system the strategy of "sequential contributions" is used on the basis of activity, andragogical, communicative, culturological and praxeological approaches. The result is an integral formulation of the concept, which includes the following. The goals and content of the pedagogical system of formation of project competence of future bachelors of social work originate from the self-project activity of students, giving them the opportunity to choose a professional orientation. Project competence implies the ability of the future social worker on the basis of his own experience of self-design to perform the functions of co-authorship in selfproject activities of the client, as well as sociopedagogical project activities in accordance with the needs of specific target groups in thesaurus and standards of social work, socio-pedagogical project activities of an innovative nature in conditions of uncertainty. At the same time, students should have an understanding of the project activities of the specialist as embedded in the broader processes of reforming the system of social services. In response to the complexity of modern social systems, the pedagogical system provides an increase in the complexity of students' project competence, increasing the number of components that they are able to understand as elementary and include in the field of their own professional activity. Communication in the pedagogical system of formation of project competence of future bachelors of social work is realized as a communication situation of "community of several". The power of the pedagogical system as a synergetic one is strengthened through cooperation and mutual assistance of students in the implementation of projects, through the development of cohesion and self-government of future bachelors, as well as through purposeful inclusion of employersmentors in the pedagogical system.

Keywords: projectcompetence, future bachelors of social work, system approach, synergetic approach, historical approach, thesaurus approach, personality oriented approach, activity approach, andragogic approach, communicative approach, culturological approach, praxeological approach, concept, pedagogical system. 
Постановка проблеми в загальному вигляді. У відповідь на зростаючу затребуваність фрахівців із соціальної роботи з виникненням нових суспільно значимих завдань відбувається профресіоналізація їх діяльності як на міжнародному, так і на національному рівнях. У 2014 році під час світового конгресу із соціальної роботи в Мельбурні було схвалене «глобальне визначення професії соціальної роботи» як заснованої на практиці професії та академічної дисципліни, що сприяє соціальним змінам та розвитку, соціальній згуртованості, активізації та звільненню людей. 3 огляду на це визначення, соціальна робота - це не лише супровід і підтримка людини у вирішенні її складних життєвих обставин, це робота 3 вирішення суперечностей, фрормування згуртованості, розвитку спроможності громад, включаючи як сервіси для інституту сім'ї, так і участь у розбудові соціальної сфрери нових для України утворень об'єднаних територіальних громад. Введено в дію Закон України «Про соціальні послуги» (Відомості Верховної Ради. 2019. № 18. Ст. 73), в якому передбачено перерозподіл повноважень між органами державної влади та місцевого самоврядування, вводиться поняття базових соціальних послуг, започатковується реєстр отримувачів і надавачів соціальних послуг. Процеси реформування галузі висувають нові вимоги до професійної підготовки соціальних працівників.

Аналіз останніх досліджень і публікацій. В Україні виконано низку ґрунтовних досліджень щодо різних аспектів профресійної підготовки, зокрема фрормування професійно-комунікативної компетентності майбутніх фрахівців соціальної роботи (В.В. Баранюк), фрункціональної компетентності майбутніх соціальних працівників із вуличної соціальної роботи (М.В. Боделан), готовності до профресійної мобільності (Г.А. Рідкодубська), науково-дослідної діяльності (О.С. Повідайчик), профресійної миследіяльності у складі методологічної роботи (Л.з. Ребуха), здоров'єзбережувальної діяльності (Л.Є. Клос), розв'язання конфліктів у профресійній діяльності (С.М. Калаур), профресійної діяльності в багатонаціональному середовищі (Ю.М. Рябова), роботи в територіальних громадах (Г.І. Слозанська).

Виділення не вирішених раніше частин загальної проблеми. На окрему увагу заслуговує проєктна компетентність як така, що покликана підготувати майбутнього бакалавра соціальної роботи до зростаючої складності сучасних соціальних систем: збільшення числа тих, хто потребує допомоги, поява нових видів складних життєвих обставин, реалізація в Україні докорінної модернізації системи соціальних послуг у зв'язку з реформою децентралізації, перехід від допомогаючої до правозахисної моделі соціальної роботи, поява нових локальних і глобальних викликів.
Метою статті є обґрунтування концепції фрормування проєктної компетентності майбутніх бакалаврів соціальної роботи.

Виклад основного матеріалу. Обґрунтування концепції фрормування проєктної компетентності майбутніх бакалаврів соціальної роботи (далі концепція) здійснюється на основі стратегії змішування методів [5], в інтеграції положень різних методологічних підходів [1, с. 165-166].

Д.Л. Морган фрормулює три стратегії, якими будемо керуватися для реалізації мети статті: 1) «перехрещення» (convergent), яка дає змогу порівняти результати різних методів, що відповідають на одне запитання, при цьому посилити результати кожного з методів, вказавши на наявні збіги результатів; 2) «додаткового покриття» (additional coverage), яка передбачає виконання різними методами різних дослідницьких завдань для розширення, насичення результатів дослідження; 3) «послідовних внесків» (sequential contributions), яка дає змогу отримати дані для входу в наступний метод, визначає логіку переходів між різними частинами дослідження [5].

Концепція фрормулюється в частинах щодо структури педагогічної системи, цілей та змісту, обґрунтування інструментарію фрормування проєктної компетентності майбутніх бакалаврів соціальної роботи.

Обґрунтування частини концепції, що визначає структуру педагогічної системи, передбачає, у першу чергу, «перехрещення» положень системного та синергетичного підходів. За основу взята класична структура педагогічної системи як системи управління у взаємозв'язках її елементів: суб'єктів та об'єктів, цілей, змісту, форми, принципів, методів і засобів організації навчання, очікуваних результатів, а також неконтрольованих зовнішніх впливів. Виходимо з визнання ролі суб'єкта управління в педагогічній системі не лише за викладачем, але й за студентами як суб'єктами самоуправління в процесі професійної підготовки. Однак що стосується суб'єктної позиції студентів, то в процесі аналізу конкретної практичної ситуації може виявлятися суперечність між потрібною готовністю студентів до самоуправління та наявністю в них пасивності, низького рівня навчальних досягнень, нерозвиненої автономності. Як відповідь на цю суперечність у педагогічній системі розглядається сукупність перехідних станів: від прямого управління діяльністю тих, хто навчається, до співуправління та самоуправління в процесі професійної підготовки. Однак у цій низці станів залишається незрозумілим механізм запуску відповідних переходів. Тому в процесі визначення структури педагогічної системи застосовується також і синергетичний підхід.

Якщо класична теорія управління передбачає наявність заданої мети, то синергетика реалізує 
динаміку, що не потребує мети як такої. Досліджуються процеси спонтанного виникнення організації як ймовірнісного процесу під впливом певних внутрішніх фракторів (серед яких важливим $є$ особистісний вибір студентів) і зовнішнього середовища (зокрема, ринку праці).

3 точки зору стратегії «перехрещення» модель педагогічної системи як системи управління та модель педагогічної системи як синергетичної системи структурно перетинаються (суб'єкт, об'єкт, цілі, впливи/зворотні зв'язки, зовнішнє середовище), але за змістом вони різняться. Такі відмінності задані не лише цілями систем, але й розширеним колом суб'єктів (викладач, студент, студентська група, лідер студентської групи, роботодавець, клієнти соціальної роботи) в синергетичній моделі, а також різними типами впливів (пряме управління, співуправління, самоуправління) в педагогічній системі як системі управління. Кожен із двох названих варіантів моделей педагогічної системи має обмеження. Якщо педагогічна система як система управління має обмеження у відсутності очевидного механізму запуску самоуправління, то синергетична модель - у ймовірнісному характері її розвитку. Тому системний і синергетичний підходи розглядаються в їх діалектиці.

Для обґрунтування частини концепції, що визначає цілі та зміст педагогічної системи, застосовується стратегія «перехрещення» положень історичного, тезаурусного й особистісно орієнтованого підходів. Беремо до уваги такі вихідні тези.

По-перше, поняття «соціальна діяльність», за М. Вебером, - це діяльність з урахуванням дій іншого і для іншого, де «інші» можуть бути окремими особами, знайомими чи групою зовсім незнайомих людей [2].

По-друге, аналіз положень історичного та тезаурусного підходів, починаючи з праць М. Річмонд (на зламі XIX та XX століть), засвідчує, що дія для іншого, допомога конкретному клієнту - це спільне з ним визначення мети, проєктування рішення для покращення складних життєвих обставин, розроблення плану дій, подальше його виконання, сприяння становленню людини як суб'єкта, здатного самостійно приймати рішення та їх реалізовувати. Тобто маємо селфпроєктну діяльність клієнта, у здійсненні якої допомагає соціальний працівник. При цьому наявне «перехрещення» 3 положеннями особистісно орієнтованого підходу, в якому також підкреслено необхідність підтримки людини в людині, актуалізації механізмів саморегуляції, саморозвитку, самореалізації через сприяння в розробленні селфпроєктів. Для того щоб соціальний працівник став співавтором та помічником у життєвому проєктуванні клієнта та поступово залучав його у самостійну діяльність та саморозвиток, соціальний працівник має володіти досвідом власної успішної селфппоєктної діяльності.
По-третє, не кожну проблему людина чи соціальний працівник може вирішити самостійно. Тому в міжнародних документах (наприклад, «Зміна характеру ринку праці» (Всесвітній банк), «Доповідь другої Всесвітньої асамблеї з проблем старіння» $(\mathrm{OOH})$ та інших) наголошується на доцільності розвитку згуртованості людей для вирішення наявних соціальних проблем. Тобто доцільно, визначаючи рівень складності проєктів, до яких мають бути підготовлені соціальні працівники, брати до уваги не лише проєкти для окремого індивіда чи сім'ї, але й проєкти для певної громади людей.

Отже, наведене зумовлює такі рівні розширення кола активності в проєктній діяльності майбутніх бакалаврів соціальної роботи: 1) для себе та найближчого оточення; 2) для знайомих, але не близьких людей; 3) для сторонніх і навіть незнайомих людей; 4) для певної громади людей.

Представлений перелік рівнів розширення кола активності отриманий теоретичним шляхом. На практиці ж було виявлено, що в умовах надання студентам свободи вибору перші свої проєкти вони, як правило, розробляють та реалізують або для інших студентів (що загалом відповідає рівню «для себе та найближчого оточення»), або для дітей, у тому числі і дітей, позбавлених батьківського піклування. Складність для студентів становить навіть не стільки розроблення та реалізація проєкту для знайомих чи незнайомих людей, скільки осмислення проєкту як комплексної діяльності, яка включає кілька взаємопов'язаних і структурованих заходів.

Важливою видається демонстрація студентам «вбудованості» діяльності фрахівця соціальної роботи в процеси, що відбуваються в галузі та державі. Маються на увазі масштабні соціальнополітичні проєкти, пов'язані 3 реформою децентралізації в Україні, переосмисленням соціальних послуг. Не менш важливими і складними є визначені на державному рівні реформи надання соціальних послуг, наприклад, для людей 3 інвалідністю або дітей, позбавлених батьківського піклування, та інших цільових груп. Відповідно до цього реалізуються соціальні проєкти місцевого рівня, які використовують професійний тезаурус соціальної роботи та стандарти надання соціальних послуг. Наведене означає, що бакалаври соціальної роботи мають розуміти власні проєкти (як правило, соціально-педагогічні) як вбудовані в ширші процеси, в загальну стратегію розбудови системи надання соціальних послуг в Україні. Навіть, наприклад, якщо йдеться про селфпроєкти самих майбутніх бакалаврів соціальної роботи, то вони мають брати до уваги ширші процеси на ринку праці.

Виходячи 3 наведеного, для формулювання концепції формування проєктної компетентності бакалаврів соціальної роботи фріксуємо необхідність 
розуміння студентами власних проєктів як вбудованих у ширші процеси реформування системи надання соціальних послуг в Україні. Також має бути враховано поступове зростання складності студентських проєктів - збільшення кількості компонентів, які майбутні соціальні працівники здатні усвідомити як елементарні в тезаурусі соціальної роботи та включити в поле власної цілеспрямованої активності.

В обґрунтуванні частини концепції дослідження, що визначає інструментарій педагогічної системи, йдеться не про конкретні методи і засоби, а про основні психолого-педагогічні теорії для подальшої конкретизації методів і засобів. Оскільки метою є не стільки досвід студентів у різних видах проєктної діяльності, скільки поступове освоєння студентами більш складної діяльності, інструментарій педагогічної системи має забезпечувати осмислення такої зростаючої складності. Основою для розроблення такого інструментарію $€$ діяльнісний підхід. Для отримання проєктної компетентності студенти мають багато практикуватися і розуміти власну діяльність в ії̈ загальності та конкретності. Загальний рівень розуміння забезпечується психологічними теоріями діяльності, зокрема, доцільним видається осмислення студентами структури діяльності, за О.М. Леонтьєвим, у декомпозиції цілей, визначенні на цій підставі комплекту завдань, дій, операцій та умов, а також, за П.Я. Гальперіним, у виокремленні в діяльності частин створення орієнтувальної основи, реалізації діяльності, аналізу отриманого результату на предмет його відповідності поставленій меті та здійснення, за потреби, корегування, що, власне, становить психологічний сенс проєктної діяльності. Педагогічна система фрормування проєктної компетентності майбутніх бакалаврів соціальної роботи має передбачити відповідний інструментарій. Також педагогічна система має включати інструментарій щодо безпосередньо проєктної діяльності, а також професійної діяльності соціальних працівників, відповідний тезаурус та професійні стандарти.

У контексті студентоцентрованого навчання, інтересів і вибору самих молодих людей при розгляді історичного, тезаурусного, особистісно орієнтованого підходів у стратегії «перехрещення» залишилася без відповіді проблема престижу професії соціального працівника. У пошуках вирішення цієї проблеми застосовується стратегія «послідовних внесків», завданням $€$ визначення інструментарію. У рамках андрагогічного підходу розглядається, за Дж. Мезіровим, поняття «трансфрормаційне навчання» як таке, що відображає виявлення та розпізнання людиною світогляду, відмінного від власного. Теорія та методика соціальної роботи містить низку модельних прикладів, що суттєво відрізняються від загальних побутових уявлень. Коли студенти починають знайомитися 3 такими прикладами, то виникає те, що Дж. Мезіров назвав дезорієнтуючою дилемою, - невідповідність між тим, що людина вважає істиною, і тим, що вона щойно пережила чи почула. Практика засвідчує, що для когось дезорієнтуюча дилема виникає у відповідь на сучасне сприйняття інвалідності в пошуку можливостей фрункціонування та забезпечення інклюзії; для інших студентів найбільш вражаюча дезорієнтуюча дилема відкривається в процесі опрацювання сучасних технологій роботи $з$ людьми, які скоїли правопорушення, та впровадження інституту пробації; певну частину молоді найбільше хвилює проблема деінституалізації в роботі з дітьми, позбавленими батьківського піклування; хтось дезорієнтуючою дилемою вважає постановку завдання підготовки майбутніх фрахівців до інноваційної діяльності, вирішення проблем, які нині невідомі. Емпіричний досвід засвідчує, що робота з цими та подібними модельними прикладами соціальної роботи за методами трансорормаційного навчання [4] є продуктивною 3 точки зору переосмислення студентами ставлення до профресії, за якою вони здобувають освіту.

Окрім діяльнісного й андрагогічного, у класі методологічних підходів, які визначають інструментальну частину концепції фрормування проєктної компетентності майбутніх бакалаврів соціальної роботи, розглядаються також комунікативний, культурологічний і праксеологічний підходи.

у комунікативному підході розкриваються три основні комунікативні ситуації: «Я - Ти», «Я - Третій», «спільність кількох». Важливість врахування положень цього підходу пов'язана 3 тим, що, задаючи певну комунікативну ситуацію, педагогічна система фрормування проєктної компетентності майбутніх бакалаврів соціальної роботи тим самим задає орієнтувальну основу для обрання тієї чи іншої комунікативної ситуації в майбутній професійній діяльності соціальних працівників. Керуємося тим, що в публікаціях 3 етики соціальної роботи дискутується питання використання ситуації «я - Ти», акцентується на важливості наявності границь у професійній комунікації соціального працівника і клієнта соціальної роботи. Натомість беремо до уваги міжнародні документи щодо розвитку згуртованості людей для вирішення соціальних проблем. 3 огляду на це доцільною для педагогічної системи формування проєктної компетентності майбутніх бакалаврів соціальної роботи визначається комунікативна ситуація «спільність кількох».

На окрему увагу заслуговує комунікація студентів між собою. Як це випливає із положень синергетичного підходу, допомогти майбутнім соціальним працівникам подолати складності (у тому числі непрестижність профресії) можна через організацію спільної роботи студентів, зокрема старших 
і молодших курсів. Емпіричним шляхом встановлено такі види залучення студентів до проєктної діяльності: 1) участь у реалізації проєкту старшокурсників, що для студентів молодших курсів $\epsilon$ орієнтувальною основою; 2) розроблення та реалізація власного проєкту окремого заходу (за підтримки студентів старших курсів); 3) розроблення та реалізація самостійного проєкту, що включає комплекс взаємопов'язаних заходів, залучення до реалізації проєкту студентів молодших курсів.

Культурологічний підхід «перехрещується» 3 комунікативним у тому, що для соціального працівника в процесі організації комунікації та розбудови «спільності кількох» важливим $є$ розуміння генези й відмінностей різних культур і релігій, вікових, гендерних і регіональних груп, субкультур, носіїв девіантної поведінки, людей, об'єднаних певними функціональними обмеженнями, людей, ізольованих за різними характеристиками.

Стосовно зв'язків студентів із роботодавцями та клієнтами соціальної роботи в процесі фрормування проєктної компетентності застосовується праксеологічний підхід як такий, що орієнтує на виконання правильних та ефективних дій майбутнього фрахівця. Правильність та ефективність досягається у зіставленні теорії, що вивчається у процесі профресійної підготовки, та практики, яку студент має спостерігати та реалізовувати у взаємодії з роботодавцем, а також в отриманні зворотного зв'язку від клієнтів соціальної роботи. Інструментарієм для цього вважається дуальна освіта, в якій важливими $\epsilon$ наставник і наставництво [3]. Варто звернути увагу й на те, що під час реалізації взаємодії студентів із роботодавцями як успішними представниками галузі соціальної роботи також відбувається позитивний вплив на вирішення проблеми непрестижності спеціальності «Соціальна робота».

Висновки. На підставі наведеного отримуємо таке інтегральне фрормулювання концепції фрормування проєктної компетентності майбутніх бакалаврів соціальної роботи.

Формування проєктної компетентності майбутніх бакалаврів соціальної роботи відбувається в умовах зростаючої складності сучасних соціальних_систем: збільшення числа тих, хто потребує допомоги; поява нових видів складних життєвих обставин; реалізація в Україні докорінної модернізації системи соціальних послуг у зв'язку з ресрормою децентралізації; перехід від допомогаючої до правозахисної моделі соціальної роботи; поява нових локальних і глобальних викликів. Разом із тим для особистості студента, який здобуває звання бакалавра соціальної роботи, зовнішні складності посилюються внутрішніми суперечностями щодо непрестижності профресії.

Педагогічна система фрормування проєктної компетентності майбутніх бакалаврів соціальної роботи розглядається як така, що реалізує в собі властивості синергетичної системи (розширення кола суб'єктів системи - викладач, студент, студентська група, лідер студентської групи, роботодавець, клієнти соціальної роботи - та забезпечення динаміки через студентське самоврядування, комбінування групової та індивідуальної навчальної діяльності), а також властивості системи управління (цілеспрямованість, надання орієнтувальної основи дії та забезпечення різних типів впливів - прямого управління, співуправління та самоуправління).

Цілі та зміст педагогічної системи беруть свій початок власне від селфпроєктної діяльності студентів - майбутніх соціальних працівників. Проєктна компетентність, що фрормується, передбачає здатність майбутнього соціального працівника виконувати фрункції співавторства в селфпроєктній діяльності клієнта соціальної роботи, соціальнопедагогічної проєктній діяльності відповідно до потреб конкретних цільових груп у тезаурусі та стандартах соціальної роботи, соціально-педагогічної проєктній діяльності інноваційного характеру в умовах невизначеності. При цьому в студентів фрормується розуміння власних проєктів як вбудованих у ширші процеси рефрормування системи надання соціальних послуг.

У відповідь на складність сучасних соціальних систем педагогічна система забезпечує зростання складності проєктної діяльності студентів: збільшення кількості компонентів, які вони здатні усвідомити як елементарні та включити в поле власної цілеспрямованої активності; урізноманітнення освоєних методів соціальної роботи; поступове розширення кола активності. Таке зростання складності осмислюється студентами через теорію діяльності.

Комунікація в педагогічній системі фрормування проєктної компетентності майбутніх бакалаврів соціальної роботи реалізується як комунікаційна ситуація «спільності кількох» за умови поваги до різноманітності людей, чим створюється відповідна орієнтувальна основа для фрахової діяльності соціальних працівників на розбудову згуртованості громад.

Підсилюється потужність педагогічної системи як синергетичної через співпрацю та взаємну допомогу студентів у реалізації проєктів, через розвиток згуртованості та самоврядування студентів, а також цілеспрямоване включення в педагогічну систему роботодавців-наставників, які посилюють орієнтувальну основу професійної діяльності, та клієнтів соціальної роботи як таких, хто надає зворотний зв'язок студентським ініціативам.

Перспективою подальших досліджень є розроблення на підставі сорормульованої концепції моделі педагогічної системи фрормування проєктної компетентності майбутніх бакалаврів соціальної роботи, а також напрацювання ії технологічного та методичного наповнення системи. 
БІБЛІОГРАФІЧНИЙ СПИСОК:

1. Бєляєв С.Б. Теоретичні і методичні засади професійної підготовки майбутніх учителів до розроблення та використання педагогічних технологій : дис. ... докт. пед. наук / Українська інженерно-педагогічна академія. 2020. 577 с.

2. Вебер М. Избранные произведения. Москва : Прогресс, 1990. 808c.

3. Світайло Н.Д. Принципи організаційного та методичного забезпечення практичної складової в рамках реалізації дуальної моделі освіти (старт в умовах багатьох невизначеностей) : навч.-метод. посібник / Н.Д. Світайло, О.В. Купенко, В.О. Дементов. Суми : СумДУ, 2019. 133 С.

4. Mezirow J. Learning to Think Like an Adult. Learning as Transformation. Critical Perspectives on a Theory in Progress. San Francisco: Jossey-Bass, 2000. P. 3-33.

5. Morgan D. Integrating qualitative and quantitative methods: A Pragmatic approach. Thousand Oaks, CA: Sage Publications. 2013. 288 p. 